Античная древность и средние века. Т. 48. С. 172-188

УДК 94(495).04/05+821.14

DOI 10.15826/adsv.2020.48.011

\author{
Л. В. Луховицкий \\ Институт славяноведения РАН \\ Москва, Россия
ХУДОЖЕСТВЕННЫЙ МИР ПОСТВИЗАНТИЙСКОЙ ХРОНИСТИКИ (на материале «Хронологического изложения» первой половины XVI в.)

В фокусе внимания автора статьи находится «Хронологическое изложение»

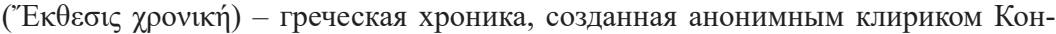
стантинопольского патриархата в первой половине XVI в. и охватывающая события поздневизантийской и ранней османской истории. Хронику отличает чередование, на первый взгляд, противоречащих друг другу точек зрения. Различные главы написаны в разных жанрах и, как кажется, перенимают систему ценностей, свойственную этим жанрам. Художественный мир глав, описывающих события до 1453 г., - это героический мир рыцарского романа. Главы, посвященные падению Константинополя, - прозаический плач об утрате города, воплощавшего в себе всю византийскую цивилизацию. В поствизантийском разделе можно выделить три модуса отношения к османам. В «апокалиптической» модели султан - нечестивец и губитель христиан; в «агиографической» («ареталогической») - философ на троне; в «прагматической»- своекорыстный, но мудрый арбитр, разрешающий споры между различными группами влияния внутри Константинопольской церкви. По мере приближения к современности хронист начинает тяготиться жанровыми формами, унаследованными от эпохи падения Константинополя, и пытается создать новый тип повествования в центре внимания оказываются герои, к которым читатель будет испытывать сочувствие вне зависимости от их религии и языка.

Ключевые слова: хронистика; поствизантийская история; Османская империя; Константинопольский патриархат; Мехмед II; Геннадий Схоларий; Константинополь; Критовул

Цитирование: Луховицкий Л. В. Художественный мир поствизантийской хронистики (на материале «Хронологического изложения» первой половины XVI в.) DOI 10.15826/adsv.2020.48.011 // Античная древность и средние века. 2020. T. 48. C. $172-188$.

Поступила в редакиию 30.06 .2020

Принята к печати 15.10.2020

(с) Луховицкий Л. В., 2020 
Художественный мир поствизантийской хронистики

\author{
Lev V. Lukhovitskiy \\ Institute of Slavic Studies of the Russian Academy of Sciences \\ Moscow, Russia

\section{IMAGINARY WORLD \\ OF POST-BYZANTINE CHRONICLE-WRITING (the Case of the Ekthesis Chronica from the First Half of the Sixteenth Century)}

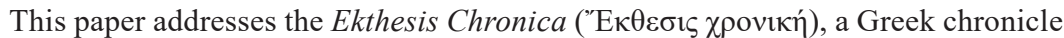
compiled by an anonymous cleric of the Patriarchate of Constantinople in the first half of the sixteenth century, which encompassed the events of the Late Byzantine and Early Ottoman history. Its distinctive feature is a recurrent alternation of seemingly mutually excluding points of view. Its neighboring chapters comply with the demands of different genres, accepting the set of values associated with them. The imaginary world of the chapters dealing with the events prior to 1453 reminds the reader of the heroic world of chivalric romances. The chapters describing the fall of Constantinople may be read as a prosaic lamentation of the loss of the city which embodied the Byzantine civilization as a whole. In the post-Byzantine section, there appeared three approaches to the Ottoman rule over the Greeks. Whenever the chronicle-writer switches to the apocalyptic mode, the sultan becomes an infidel murderer of Christians. If, by contrast, he adopts the aretalogic (hagiographic) mode, the same sultan transforms into a philosopher on the throne. Finally, the pragmatic mode makes him a self-serving albeit sympathetic moderator in the conflicts inside the Patriarchate of Constantinople. The closer is the author to contemporary history, the more unfitting he feels the generic forms inherited from the age of the fall of Constantinople. Eventually, the chronicle-writer makes an attempt to create a new type of narrative with the characters on the foreground, which will allow his reader to feel empathy for them notwithstanding their language and faith.

Keywords: chronicle-writing; post-Byzantine history; Ottoman empire; Patriarchate of Constantinople; Mehmed II; Gennadios Scholarios; Constantinople; Kritoboulos

For citation: Lukhovitskiy, L. V. (2020). Khudozhestvennyi mir postvizantiiskoi khronistiki (na materiale "Khronologicheskogo izlozheniia" pervoi poloviny XVI v.) [Imaginary World of Post-Byzantine Chronicle-Writing (the Case of the Ekthesis Chronica from the First Half of the Sixteenth Century)]. Antichnaya drevnost' $i$ srednie veka, 48, 172-188. doi: 10.15826/adsv.2020.48.011

Submitted: 30.06 .2020

Accepted: 15.10.2020 


\section{Л. В. Луховицкий}

Цель настоящей статьи ${ }^{1}$ - предложить литературное прочтение поствизантийского памятника греческой хронистики, который часто используется специалистами по поздневизантийской и ранней османской истории, но почти никогда не попадает в фокус внимания исследователей византийской литературы. Реконструкция художественного мира этой хроники оказывается далеко не тривиальной задачей, поскольку соседние разделы сочинения демонстрируют полностью различные, подчас диаметрально противоположные, идеологические установки, благодаря чему читатель одной главы видит мир, описанный (или, скорее, созданный) хронистом, принципиально иначе, чем читатель последующей или предшествующей главы. Одним из возможных путей разрешить это противоречие была бы деконструкция - расслаивание хроники и выявление в ее составе частей, восходящих к разным источникам, возникшим в разных культурных контекстах. Такой метод успешно используется при работе с текстами, созданными в интересующую нас эпоху и посвященными истории Балкан $\mathrm{XIV}-\mathrm{XV}$ вв. ${ }^{2}$. Однако, на мой взгляд, можно применить и принципиально иной подход, присваивающий определяющую роль не источнику, а жанровой ориентации. Как мне кажется, хронику можно прочитать как цельное произведение при допущении, что приспособление к законам жанра для ее автора выходит за рамки стиля и повествовательной манеры и распространяется также и на систему ценностей. Переключаясь между жанрами, хронист развоплощается и на одной странице оплакивает падение православной столицы от рук неверных, а уже на другой - рисует властителя этих неверных философом на троне и едва ли не тайным христианином. Вопрос лишь в том, есть ли у нас средства заглянуть в зазор между масками и увидеть того, кто меняет их.

Поствизантийская хронистика - трудноуловимый объект для исследования. Некоторые хроники остаются неизданными (такова, например, «Всемирная хроника 1570 г.» Мануила Малакса, чей оригинал находится в библиотеке Монастыря св. Креста в Иерусалиме $\left.{ }^{3}\right)$, а некоторые прекрасно известны, поскольку попали в руки европейских исследователей

\footnotetext{
${ }^{1}$ В основу статьи положен доклад, прочитанный на XIX конференции памяти В. Д. Королюка «Славяне и их соседи в многоконфессиональном мире (позднее Средневековье и раннее Новое время)» (10.12.2019, Москва, Институт славяноведения РАН).

${ }^{2}$ Полывянный Д. И. «Болгарская анонимная хроника»: опыт аналитической декомпозиции. doi: 10.15688/jvolsu4.2019.6.14 // Вестник Волгоградского государственного университета. Серия 4, История. Регионоведение. Международные отношения. 2019. Т. 24, № 6. С. 173-183.

3 Оцифрованная версия рукописи Sanctae Crucis 28 доступна в коллекции Library of Congress Collection of Manuscripts in the Greek Orthodox Patriarchate of Jerusalem: URL: https://www.loc.gov/item/00279395499-jo/ (дата обращения: 20.05.2020). О ней: Sakel D. The Chronicle of 1570: The Original Version // BZ. 2013. Bd. 106, H. 1. S. 143-152. DOI: 10.1515/bz-2013-0011; Idem. The Manuscripts of the Chronicle of 1570 // Byz. 2013. T. 83. P. 363-374. DOI: 10.2143/BYZ.83.0.2988923
} 
Художественный мир поствизантийской хронистики

фактически сразу после создания. Такова знаменитая «История патриархов» того же Мануила Малакса, которая была создана в конце 1570-х гг. и уже в 1584 г. напечатана Мартином Крузием (1524-1607) в Базеле, а в XIX в. переиздана в Боннском корпусе византийских историков ${ }^{4}$.

Интересующий нас корпус текстов ставит филолога-классика в тупик. Дело в том, что мы не всегда можем сказать, где пролегает граница между произведениями: в каком случае мы имеем дело с самостоятельным сочинением (пусть и основанным на более ранних источниках), в каких - с переложением (эпитомой или метафразой), а в каких - с текстуальным вариантом уже известного нам произведения. Построить классическую стемму кодексов невозможно, пытаться издавать критически - тоже. Достаточно сказать, что, согласно М. Филиппидису, в основе разветвленной хронографической традиции конца XVI в. лежит доведенная до 1572 г. «Патриаршая хроника» митрополита Артского и Навпактского Дамаскина Студита, а сочинения Мануила Малакса и псевдо-Сфрандзи (Макария Мелиссурга-Мелиссена) - не более чем ее переработки ${ }^{5}$ Конкурирующая реконструкция, напротив, усматривает в труде Дамаскина Студита, равно как и в «Исторической книге» псевдо-Дорофея Монемвасийского и еще нескольких источниках, всего лишь текстуальный вариант «Всемирной хроники 1570 г.» Мануила Малакса 6 .

Однако, кем бы в действительности ни был хронист, взявшийся в 1570-е гг. за рассказ о первых десятилетиях османского господства в Константинополе, его основным источником стал более ранний анонимный текст, носящий в рукописях название «Хронологическое

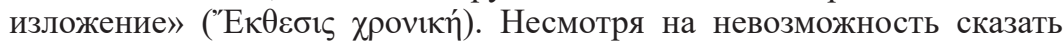
что-либо определенное о его авторе кроме того, что он принадлежал к церковным константинопольским кругам, текстологические проблемы и наличие нескольких версий (различные списки доводят повество-

\footnotetext{
${ }^{4}$ Historia politica et patriarchica Constantinopoleos. Epirotica / ed. I. Bekker. Bonn, 1849. P. 77-204.

${ }^{5}$ Библиографию по вопросу см. в: Philippides M. Damaskenos the Studite // Historians of the Ottoman Empire / eds. C. Kafadar, H. Karateke, C. Fleischer. URL: https://ottomanhistorians. uchicago.edu/en/historians/26 (дата обращения: 28.05.2020). Из более поздних публикаций отметим: Philippides M., Hanak W. K. The Siege and Fall of Constantinople in 1453: Historiography, Topography, and Military Studies. Farnham ; Burlington, 2011. P. 51-62.

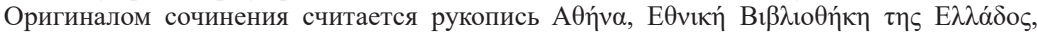

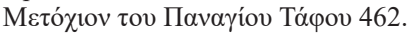

${ }^{6}$ Sakel D. A Probable Solution of the Problem of the Chronicle of the Turkish Sultans // Byzantine Narrative: Papers in Honour of R. Scott / eds. J. Burke et al. Leiden ; Boston, 2006. P. 204-220. DOI: 10.1163/9789004344877_016; Idem. A Non-Existent Byzantine-Style Historian in a New Encyclopaedia of Ottoman Historians // REB. 2010. T. 68. P. 209-217. DOI: 10.3406/rebyz.2010.3071; Idem. An Addendum on Codex Constantinopolitanus

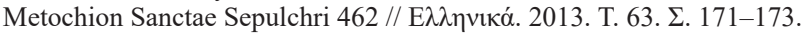




\section{Л. В. Луховицкий}

вание до 1513, 1517 и даже 1543 г.), это сочинение хорошо известно в науке и несколько раз публиковалось ${ }^{7}$.

Греческую литературу эпохи османского господства характеризует определенная раздвоенность сознания, в котором неизменно присутствуют две магистральные линии отношения к османам: антитурецкая (условная парадигма историка Дуки, согласно которой султан -

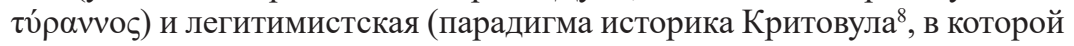
султан, напротив, - только $\beta \alpha \sigma \imath \lambda \varepsilon u ́ \varsigma)$. Можно было бы предположить, что по мере удаления от трагических событий падения Константинополя первая уйдет на второй план, поскольку ужасы 1453 г. забудутся и новое устройство жизни из пугающего новшества превратится в привычный уклад. Но в действительности эта линия просто перемещается в область литературы: плачи о падении Константинополя в начале XVII в. пишутся так, как будто бы с 1453 г. не прошло ни дня, и турки - это варвары, убийцы, нечестивцы и предтечи Антихриста. В то же время, хроники, излагающие историю недавнего прошлого, написаны так, что турецкая власть в них оказывается гарантом безопасности и защитником греческого христианского населения от боярского произвола в Дунайских княжествах. Примечательно, что автором подобного плача и подобной хроники мог быть один и тот же писатель'.

Но как поступить, если перед историком стоит задача создать повествование с более широким временным охватом, рассказав на протяжении одного текста сначала о падении Константинополя, а затем - о том, что происходило полвека спустя? Подчеркну, что предложенное ниже чтение ни в коей мере не претендует на то, чтобы заменить собой классическое источниковедение. Строить гипотезы об источниках, лежащих в основе «Хронологического изложения», можно и нужно, но моей задачей будет посмотреть на текст как целое -

\footnotetext{
7 Ecthesis Chronica and Chronicon Athenarum / ed. with critical notes and indices by S. P. Lambros. London, 1902; Emperors, Patriarchs, and Sultans of Constantinople, 13731513: An Anonymous Greek Chronicle of the Sixteenth Century / introd., transl. and comment. M. Philippides. Brookline (Mass.), 1990 (далее - Ecthesis). В основу издания положен список Oxford, Lincolnensis gr. 10 (нач. XVII в.).

${ }^{8}$ Терминология предложена в работе: Todorova M. Imagining the Balkans. Oxford, 1997. P. 166. Подробнее о тенденциях греческой общественной мысли эпохи см.: Moustakas K. Byzantine "Visions" of the Ottoman Empire: Theories of Ottoman Legitimacy by Byzantine Scholars after the Fall of Constantinople // Images of the Byzantine World: Visions, Messages and Meanings: Studies Presented to L. Brubaker / ed. A. Lymberopoulou. Farnham ; Burlington, 2011. P. 215-229.

9 Vincent A. Byzantium Regained? The History, Advice and Lament by Matthew of Myra // Thesaurismata. 1998. Т. 28. Р. 275-347; Луховицкий Л. В. «Умер нечестивый эмир... он очень любил и самих христиан, и церковь Христову»: Греческое самосознание в хронистике начала XVII в. // Кафедра византийской и новогреческой филологии / ред. М. В. Бибиков, К. А. Климова. М., 2016. Вып. 2. С. 30-43.
} 
Художественный мир поствизантийской хронистики

глазами его читателя-современника, который со всей очевидностью не занимался выявлением источников, а читал лежащий перед ним текст как единый нарратив ${ }^{10}$.

Произведение открывает история про подавление двумя отцами мятежа двух сыновей: Иоанн V Палеолог в 1373 г. ослепляет своего сына Андроника и одновременно своего сына ослепляет Мурад I. «Ва-

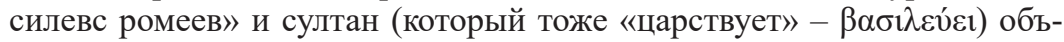
единены общим делом. Рассказчик не позволяет себе произносить какие-либо уничижающие эпитеты в адрес султана. Они с византийским

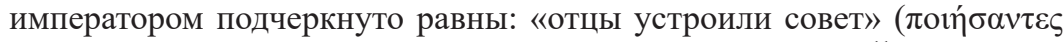

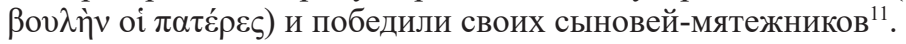

Особые отношения между императором и султаном сохранятся и в дальнейшем: когда Мануил II Палеолог просит Мурада II, ссылаясь на их «дружбу» не нападать на Фессалонику, тот отвечает ему: «Будь она твоя, я бы не шел на нее походом, но она венецианская, поэтому я иду, чтобы, если Бог того захочет, захватить ее» ${ }^{13}$. Рассказ строится так, как будто бы у мусульман и христиан один Бог, ведь уже в следующей главе о том же событии, падении Фессалоники в 1430 г., но уже с позиции рассказчика, будет сказано, что город пал «по Божьему попущению за наши грехи» ${ }^{14}$. Формально султан - предводитель нечестивцев ( $\left.\dot{\alpha} \sigma \varepsilon \beta \varepsilon \tilde{\imath} \varsigma\right)$, но все же, как он и надеялся, Бог даровал ему победу. Османы и византийцы существуют в одной системе координат.

Дистанция между их системами ценностей несопоставима с той, что разделяет православных и католиков. Этот разрыв действительно

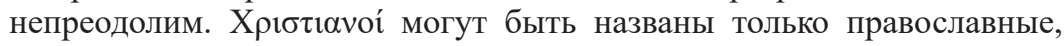
а все католики сливаются в нерасчленимое единство двуличных франков / венецианцев / латинян. Захватив Фессалонику, Мурад «убил много христиан $<\ldots>$ Ведь немногочисленные франки бежали, и только исконные жители претерпели такое, что и рассказать нельзя» ${ }^{15}$. Примечательно, что в более поздних версиях тех же рассказов, созданных Мануилом Малаксом и Феодосием Зигомалой для Мартина Крузия, отноше-

\footnotetext{
${ }^{10}$ Вопрос достоверности сообщений «Хронологического изложения» нас не интересует, поскольку я исхожу из предпосылки, что читатель верил рассказчику на слово. Ниже я свожу к минимуму ссылки на исследования, посвященные историческому анализу упоминаемых сюжетов, но при этом привожу типологические литературные параллели из других эпох.

${ }^{11}$ Ecthesis. P. 24. Cap. 1.

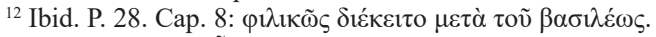

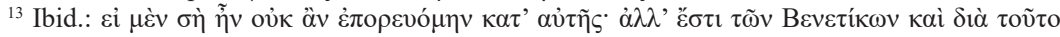

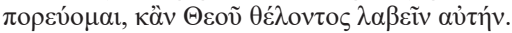

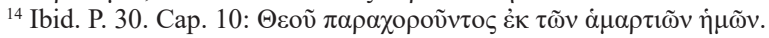

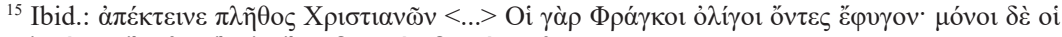

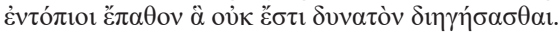




\section{Л. В. Луховицкий}

ние к католикам будет куда более терпимое, а Ферраро-Флорентийский собор даже будет назван «Восьмым Вселенским» ${ }^{16}$.

Исключительно интересен рассказ о событиях 1444 г., когда в поход против турок выступил венгерский и польский король Владислав III. Согласно анонимному хронисту, византийский император пообещал воеводе Яношу Хуньяди славу «освободителя христиан и нашей веры», если тот выгонит турок «с Запада» ${ }^{17}$. Но венгерское войско перешло Дунай, захватило Варну и стало «каждый день уничтожать христиан», предаваясь пьянству и блуду ${ }^{18}$. Услышав об этом, Мурад II был вынужден вернуться из Магнезии. Но тут категории неожиданно расплываются: встревоженные визири пишут султану о «грехе, который ляжет на его душу», о недопущении «уничтожения нашего рода» ${ }^{19}$ (но ведь только что речь шла об убийстве христиан!). Неужели у султана те же представления о «грехе», что и у автора и потенциального читателя «Хронологического изложения»? Характерно и слово «род», входящее в классическую формулу византийской самоидентифика-

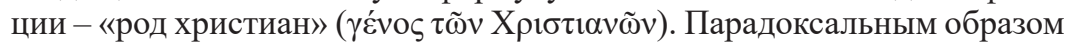
в интересующем нас эпизоде турки выступают как защитники «христиан» от венгров - мнимых защитников христиан.

Но и венгры - не исчадия ада. Они, скорее, антигерои, чем злодеи. То, как они обсуждают, кто поведет войско дальше после очередной победы («если Бог будет благосклонен и я выйду победителем, [вознесем] ему благодарность...» $\left.{ }^{20}\right)$, показывает, что они существуют в той же ценностной системе, что и византийцы. Но все портит дур-

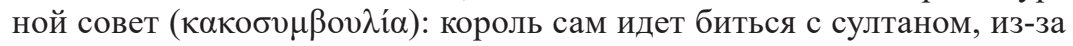
гордыни не желая делиться славой с более опытным военачальником, и нелепо погибает. Показательно, что слова «вот что сотворил дурной совет» звучат в произведении уже не первый раз. Сходная фраза завершает одну из первых глав, в которой окружение императора Иоанна V советует ему не целовать в Италии руку «латинского епископа», из-за чего папа Римский выходит из себя и запрещает кому бы то ни было «из своего рода» помогать византийцам ${ }^{21}$. Ситуация повторяется: снова некие не названные по именам приближенные царя

\footnotetext{
${ }^{16}$ Moustakas K. The Logic of Historical Thematology in the Historia Politica Constantinopoleos and the Historia Patriarchica Constantinopoleos // Festschrift in Honor of I. P. Theocharides: Studies on the Ottoman Empire and Turkey. Vol. 2 / eds. E. Balta, G. Salakidis, Th. Stavrides. Istanbul, 2014. P. 370-371.

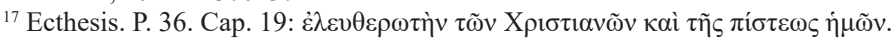

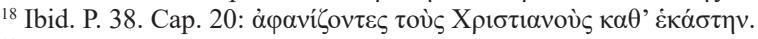

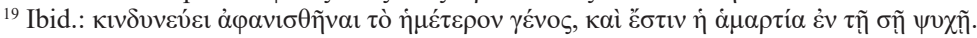

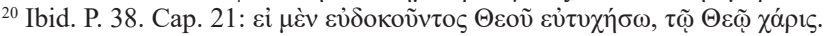

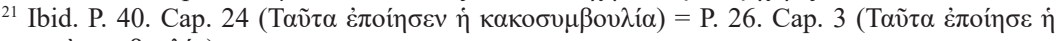

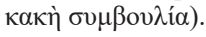


Художественный мир поствизантийской хронистики

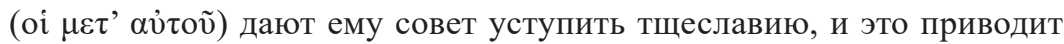
к губительным последствиям.

В рассказе о событиях до падения Константинополя венгры, турки и византийцы разделяют одни и те же представления о добре и зле. Император, султан и король - это равные правители (статус византийского императора не представлен как принципиально отличный от статуса короля венгров), существующие в рыцарской (возможно даже, романной) системе ценностей: их дворы как в зеркале отражают друг друга (везде в центре композиции оказывается король-воин, а вокруг него снуют помощники, готовые дать «дурной совет»); они человеколюбивы и одинаково понимают свой долг перед «родом», полагаются на «Бога» (без каких-либо уточнений), вступают в отношения «дружбы» друг с другом и подвержены одним и тем же искушениям тщеславием. Формально один из этих королей-воинов - иноверец и нечестивец, но этот эпитет стерт и не играет какой-либо роли. Неожиданным образом прошлое, нарисованное хронистом, оказывается очень похоже на мир рыцарского романа или на эпическое прошлое поэмы о Дигенисе Акрите, в котором арабы и византийцы называют друг друга «псами», но при этом сосуществуют в общей героической системе координат ${ }^{22}$.

Но вдруг ситуация радикально меняется. Султан приобретает новое качество, которое в первых главах было зарезервировано для латинян, - коварство: Мехмед II задумал нечто горестное для «христиан и Города». Сначала он «притворился другом горожан», но эта дружба была ложью ${ }^{23}$. Византийцев погубило слепое доверие клятвам, которые принес отец Мехмеда, а он сам подтвердил. В последующих главах мы наконец встречаем ту зашкаливающую концентрацию пейоративов в адрес турок, которую рассчитывали увидеть много раньше: они «беззаконные враги» ( $\dot{\chi} \theta \rho \tilde{\omega} v \dot{\alpha} v o ́ \mu \omega v)$, «ненавистнейшие отступники» ( $\dot{\varepsilon} \theta \dot{i} \sigma \tau \omega \nu \alpha \dot{\alpha} \sigma \sigma \tau \alpha \tau \tilde{\omega} \nu)$, а их правитель - «неправедный и самый ковар-

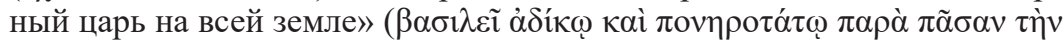

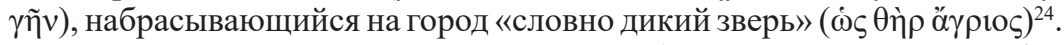
Хронист меняет и стилистический регистр (главы, посвященные событиям 1453 г., изобилуют риторическими восклицаниями, вопросами, воззваниями к Богу), и применяет весь арсенал средств, чтобы впервые (и так поздно!) описать проигранную византийцами борьбу с турками

22 Литература по вопросу очень обширна, из новейших работ можно отметить Jouanno $C$. Shared Spaces: 1. Digenis Akritis, the Two-Blood Border Lord // Fictional Storytelling in the Medieval Eastern Mediterranean and Beyond / eds. C. Cupane, B. Krönung. Leiden, 2016. P. 268-269. (Brill's Companions to the Byzantine World ; 1).

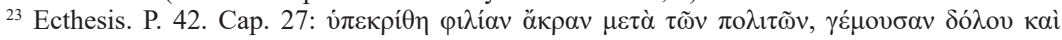

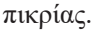

${ }^{24}$ Ibid. P. 48-50. Cap. 33-34. 


\section{Л. В. Луховицкий}

как цивилизационное противостояние. Турки вдруг оказываются носителями принципиально иной системы ценностей, чем византийцы: они насилуют монахинь и оскверняют могилы ${ }^{25}$. Вполне ожидаемо, что действующей силой, предавшей за грехи греков город в руки врага, в видении хрониста, оказывается Бог. Но теперь просто невообразимо,

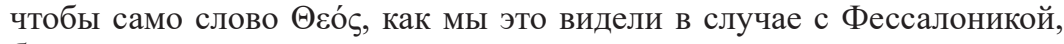
было вложено в уста султана.

Однако превращение антигероя в злодея не окончательно, и в самом пространном и важном разделе сочинения, посвященном событиям после 1453 г., можно выделить три параллельных модуса рассказа о турках и, соответственно, три портрета Мехмеда ${ }^{26}$.

По-прежнему важную роль играет Мехмед - «губитель и убийца

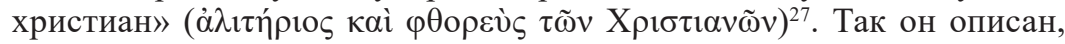
когда речь заходит о насильственной репопуляции Константинополя выходцами из захваченных земель. Когда хронист пишет о восстановлении Константинопольского патриархата, для него важна не религиозная терпимость, а коварство Мехмеда. Он позволил грекам избирать себе патриарха не из человеколюбия, а «хитро, как лис» $(\tau \varepsilon \chi \nu \eta \varepsilon \dot{\varepsilon} \tau \omega \varsigma \dot{\omega} \varsigma \dot{\alpha} \lambda \dot{\omega} \pi \eta \xi)^{28}$, рассчитывая, что благодаря этому рассеянные по всем землям империи греки-христиане вернутся в столицу и окажутся под его присмотром.

Но вдруг благодаря патриарху Геннадию Схоларию с султаном происходит трансформация. После их беседы «султан получил точные доказательства истинности христианской веры и стал смотреть на наш род благосклонно, ведь он был рад, что стал предводителем такого народа мудрецов и учителей» ${ }^{29}$.

\footnotetext{
${ }^{25}$ Ничего неожиданного в подобном портрете нет. Прекрасной иллюстрацией подхода, рисующего конфликт между византийцами и турками как цивилизационное противостояние, может стать, к примеру, сочинение Иоанна Канана: Ioannis Canani de Constantinopolitana obsidione relatio: a Critical Edition, with English Translation, Introduction, and Notes of John Kananos' Account of the Siege of Constantinople in 1422 / ed. A. M. Cuomo. Boston ; Berlin, 2016.

${ }^{26} \mathrm{O}$ противоречивых портретах Мехмеда II у историков XV в. см.: Reinsch D. R. Mehmet der Eroberer in der Darstellung der zeitgenössischen byzantinischen Geschichtsschreiber // Sultan Mehmet II. Eroberer Konstantinopels, Patron der Künste / eds. N. Asutay-Effenberger, U. Rehm. Köln, 2009. S. 15-30. О неоднозначности образа Мехмеда в «Хронологическом изложении» см.: Moustakas K. Ottoman Greek Views of Ottoman Rule $\left(15^{\text {th }}-16^{\text {th }}\right.$ Centuries): The Perspective of the Patriarchate Associates // Political Thought and Practice in the Ottoman Empire: Halcyon Days in Crete 9: A Symposium Held in Rethymno 9-11 January 2015 / ed. M. Sariyannis. Rethymno, 2019. P. 311-318.

${ }^{27}$ Ecthesis. P. 54. Cap. 39.

${ }^{28}$ Ibid. P. 56. Cap. 40.

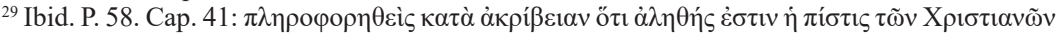

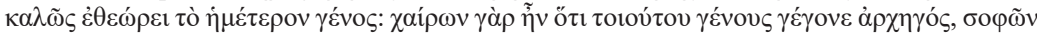

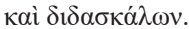


Художественный мир поствизантийской хронистики

По словам хрониста, когда на Константинопольском престоле оказывается достойный патриарх, даже в условиях турецкого господства, в церкви вполне возможен «мир и порядок»: «Когда он [Дионисий I] занимал престол, враг Диавол позавидовал миру и порядку церквей и посеял плевелы [в душах] клириков...» ${ }^{30}$. Подобный зачин можно прочитать в любом византийском ересиологическом сборнике, начиная с трактата Германа Константинопольского (715-730) «О соборах и ересях» ${ }^{31}$. В подобного рода текстах история Церкви представлена как череда покушений: вновь и вновь Диавол завидует миру, царящему во Вселенской Церкви; не имея возможности разрушить ее снаружи, он пытается посеять раздор внутри нее; и хотя каждая атака заканчивается неудачей, он никогда не оставляет своих попыток. Формулы, которые использует анонимный хронист, настолько знакомы, что, прочитай мы эту фразу вне ее контекста, мы никогда не догадались бы, что речь идет о временах, когда на Константинопольском троне восседает не христианнейший государь, а правитель-мусульманин.

Но образ Мехмеда-мудреца не завершает картину, поскольку через несколько глав читатель сталкивается с еще одним героем Мехмедом-политиком. В логике хрониста восстановление Константинопольского патриархата приводит к ожесточенным внутрицерковным конфликтам. Одни группы архиереев выступают против других, они делают ставки на разных кандидатов в патриархи и стараются перекупить место, обещая османским властям больше денег. Практика уплаты взноса при восхождении на престол нового патриарха закрепляется вовсе не по злой воле султана, а из-за мелких дрязг внутри самой Константинопольской церкви. Противники патриарха Марка (1466), желавшие видеть на престоле своего ставленника Симеона Трапезундского, оклеветали Марка, будто бы он внес при вступлении на престол тысячу монет, тогда как на самом деле, по словам хрониста, «ни он ничего не давал, ни до него другие патриархи» ${ }^{32}$. Трапезундские богачи и кое-кто из жителей Константинополя собрали сумму, соответствовавшую той, что звучала в рассказах о Марке, и принесли султану. Тот, прекрасно понимая, в чем дело, только улыбнулся (показательно использован глагол, который, как правило, описывает кротость святых в византийской агиографии) и воспользовался возможностью: «Властитель понял, что они ничего на самом

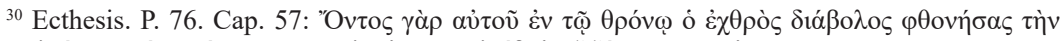

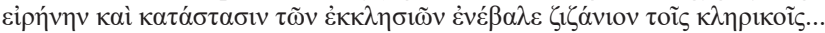

${ }^{31}$ Germani Constantinopolitani De haeresibus et synodis // Spicilegium Romanum / ed. A. Mai. Vol. 7. Roma, 1842. P. 1-74.

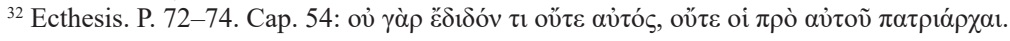




\section{Л. В. Луховицкий}

деле не знают, улыбнулся и сказал: “И правда, он внес эти деньги. Но раз вы его не хотите, делайте патриархом того, кто вам мил”» ${ }^{33}$.

Попробуем дать трем выделенным модусам условные названия: в апокалиптической линии султан - завоеватель и губитель христиан, в ареталогической - философ на троне и покровитель культуры, в прагматической - своекорыстный, но иногда мудрый арбитр в споpax между настоящими интриганами и подлецами внутри Константинопольской церкви.

При этом мы не наблюдаем никакой динамики: ни одна из линий не отходит на второй план, а все три сосуществуют в параллельных плоскостях. В главах, посвященных походам Мехмеда II, хронист восклицает: «Этот разбойник и губитель христиан не успокаивался ни на год, но ежегодно приводил несчастных христиан как стада овец, и кого продавал, кого отдавал в подарок. О, владыка вседержитель, сколь велико твое долготерпение!»34. Но всего две главы спустя читателя ждет идеализированная картина мирного сосуществования греков-христиан и османов, поскольку хронист переключается в ареталогический (или даже агиографический) режим. По его словам, при патриархе Максиме (1476-1482) «в Церкви царил мир, поскольку все скандалы улеглись» ${ }^{35}$. Патриарх каждое воскресенье произносил с амвона проповедь и был

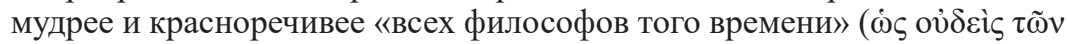

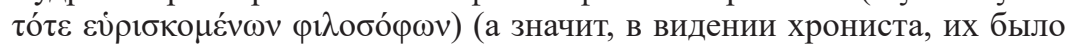
много!). Но вот «его слава достигла слуха властителя» и тот попросил у него письменное «изъяснение символа нашей веры» ${ }^{36}$. Султан при-

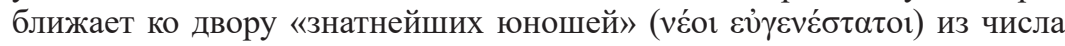
греков, которые переводят на доступный ему язык христианские книги, а он «непрестанно расспрашивает их о таинствах нашей веры» ${ }^{37}$. Мехмед читает их, особенно интересуясь рассказами о сверхъестествен-

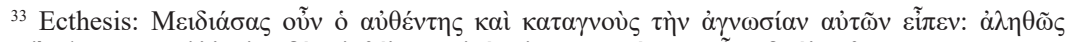

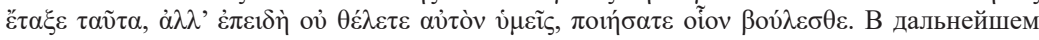
рост выплат при вступлении нового патриарха на престол объясняется исключительно личными амбициями претендентов на престол и их покровителей. Когда Мара Бранкович внесла за Дионисия I 2 тысячи монет, столько стали требовать и со всех последующих патриархов. Обещание увеличить выплаты мы видим у самых отрицательных героев, например, у патриарха Рафаила I (1475-1476) из Сербии, которого хронист ненавидит из-за его пьянства и «чужеречия» (Ibid. P. 78. Cap. 59; P. 80. Cap. 61).

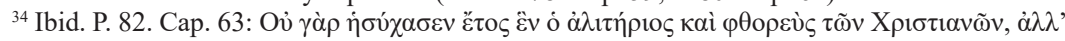

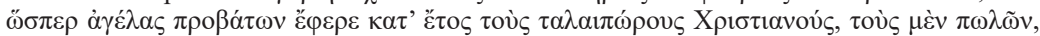

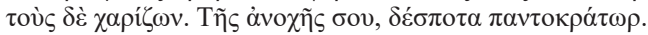

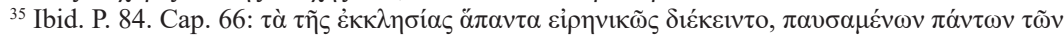
$\sigma \kappa \alpha \nu \delta \alpha ́ \lambda \omega v$.

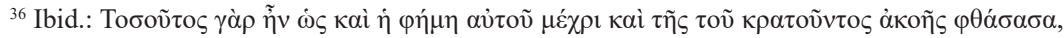

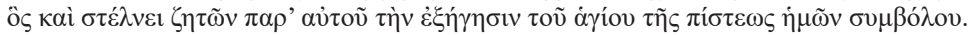

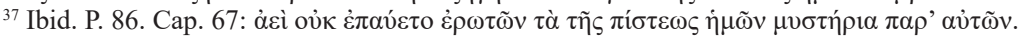




\section{Художественный мир поствизантийской хронистики}

ном, и даже становится свидетелем настоящего чуда, когда убеждается, что давно погребенное тело отлученной клеветницы почернело и раздулось, но не подверглось тлению. В итоге султан «поверил, что вера христиан истинна» ${ }^{38}$.

Когда читатель слышит, что Мехмед II был «страшнее всех прежних василевсов» ${ }^{39}$, перед его мысленным взором встает не череда османских султанов-предков Мехмеда, а сонм византийских императоров. Султан обладает всеми добродетелями достойного правителя: он был нетерпим к любой несправедливости со стороны своих приближенных, поэтому «все его сановники дрожали перед его лицом», но щедр и справедлив. Он приближал к себе мудрецов «не только из своего рода, но и из нашего» ${ }^{40}$ и, будучи судьей в песенном состязании греков и перса, «был поражен изяществом ромеев»и присудил им победу ${ }^{41}$. Глава, подводящая итог правлению Мехмеда, могла бы быть написана и про христианского правителя. Она наполнена топосами рассказа о благочестивом царе и в ней сквозит горечь от того, что даже великие государи - всего лишь простые смертные: «Он превзошел знаниями и мудростью всех своих предшественников. Он расширил пределы своего царства на всю Азию и Европу. Но и он должен был заплатить всеобщий долг. Даже и такое благоденствие не помогло ему, и он принял смерть как всякий тленный человек...» ${ }^{42}$. Важно подчеркнуть, что анонимный хронист был далеко не первым, кто использовал, говоря о Мехмеде, образность и формулы, которые в византийской традиции были зарезервированы для благочестивых императоров. То же самое делал, к примеру, Георгий Амируци, применяя в обращении к Мехмеду весь арсенал топосов торжественной византийской поэзии: Константинополь как невеста встречает своего жениха, возвращающегося из похода с победой, а тот вновь дарит ей молодость, а природе - весну и цветение ${ }^{43}$. Разница заключается лишь в том, что Амируци последовательно проводил одну и ту же

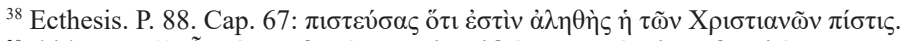

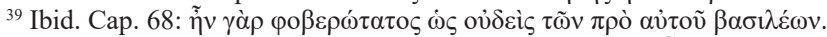

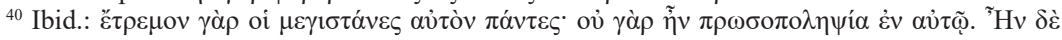

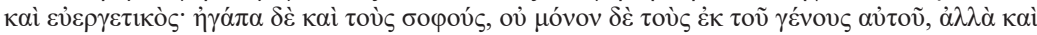

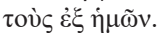

${ }^{41}$ Ibid. P. 90. Cap. 69.

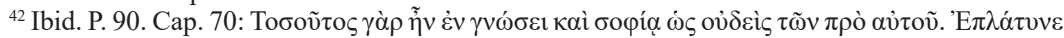

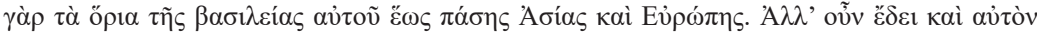

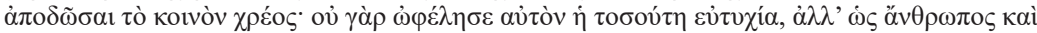

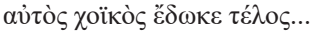

${ }^{43}$ Reinsch D. R. Byzantinisches Herrscherlob für den türkischen Sultan: Ein bisher unbekanntes Gedicht des Georgios Amirutzes auf Mehmed den Eroberer // Cupido legum / hrsg. L. Burgmann, M. Th. Fögen, A. Schminck. Frankfurt am Main, 1985. S. 195-210.
} 


\section{Л. В. Луховицкий}

идеологическую линию во всех своих произведениях, а автор «Хронологического изложения» кажется не равным самому себе.

Однако чем больше на портрете султана проступает черт византийского императора, тем более размытой становится самоидентификация рассказчика. «Мы» и «наше» хрониста никак не эксплицируются, и понять, что за ними скрывается, можно только по косвенным признакам $^{44}$. Когда хронист пишет о расширении империи Мехмедом, это еще может быть взгляд со стороны - попытка объективно оценить успехи правителя, вне зависимости от его веры. Но в определенный момент хронист начинает принимать победы османского оружия на свой счет. Особенно легко это сделать, если турецкая агрессия направлена на земли «франков». Рассказывая о том, как османский сановник Ахмет Паша был казнен из-за зависти, хронист с горечью замечает, что он «был всеми любим за то, что принес много побед» ${ }^{45}$. Местоимение «все», видимо, включает и греков-христиан. Турецкой победой, которой могут гордиться греки, ожидаемо оказывается взятие Отранто в 1480 г.

Три выделенные нами схемы прекрасно уживаются друг с другом и позволяют хронисту маневрировать и манипулировать читателем. Ареталогический модус, который мы видим в главе про Баязида II (1481-1512) (все в его правление процветало, а сам он был «скромным, мирным и справедливейшим» $\left.{ }^{46}\right)$, легитимизирует его статус ограничителя прав христиан. Уже в следующей главе султан низлагает Константинопольского патриарха Иоакима I за то, что тот возвел христианский храм $^{47}$. Но этот шаг, в видении хрониста, никак не противоречит его справедливости и представлен, скорее, не как акт подавления свободы вероисповедания, а как нелепое происшествие, объясняющееся «про-

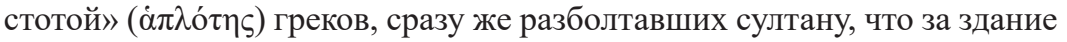
он видит и по чьему разрешению оно построено.

Но история, с которой имеет дело писатель, не умещается даже в эти три схемы. Читая хронику, мы постоянно сталкиваемся с нереализованными возможностями, когда, казалось бы, законы жанра(-ов) требуют от историка обращения к неким топосам, но тот отказывается их использовать, будучи увлечен живой человеческой историей, которую рассказывает. В очередном рассказе о династической борьбе между несколькими претендентами на турецкий престол возникает ощущение, что рассказчик упускает из виду тот самоочевидный факт, что это,

\footnotetext{
${ }^{44}$ Cp.: Shawcross T. The Chronicle of Morea: Historiography in Crusader States. Oxford, 2009. P. 190-193. «Морейская хроника»с ееуникальной протонационалистической программой могла бы стать интересной типологической параллелью к поствизантийским хроникам.

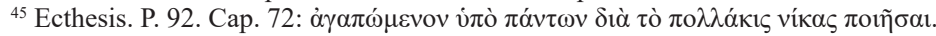

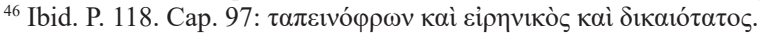

${ }^{47}$ Ibid. P. 120. Cap. 99.
} 
Художественный мир поствизантийской хронистики

строго говоря, не его история. Когда один из героев отправляется «с

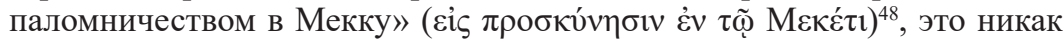
не поясняется и не осуждается, нет никаких уничижительных эпитетов, которые должна была бы предлагать хронисту сама многовековая византийская традиция полемики с исламом. Увлекшись человеческой историей, хронист, как кажется, «забывает» наводнить свой текст нужными пейоративными эпитетами.

Та же «забывчивость» стоит и за некоторыми внешнеполитическими эпизодами. Поразительным образом, излагая события турецковенецианской войны 1499-1503 гг., рассказчик настолько увлекается героической фигурой венецианского капитана Лоредано, что начинает смотреть на происходящее его глазами и едва ли не отождествляет себя с католиками. Лоредано, по его словам, мстит турецкому генералу Кемалю за то, что тот «разорял всю Италию, уводя в плен и губя христиан» ${ }^{49}$. Незыблемое для начала «Хронологического изложения» противопоставление «христиане-греки» и «франки» оказывается неактуально, и католики из Италии становятся такими же «христианами», что и греки в Константинополе.

Но в действительности определяющим является вовсе не религиозный, а человеческий критерий. Рассказывая о новом этапе внутридинастической борьбы в Османской империи, автор вновь увлекается и теперь как будто отождествляет себя с героями этой (уже точно чуждой ему) истории. Именно так изложены события прихода к власти Селима I (1512-1520). В интересующем нас эпизоде есть свой герой, Баязид, - мудрый старик, не желающий войны с собственным сыном, и свои антигерои - янычары, которые, «как дикие звери», поджидают, когда султан сдаст власть. Конечной движущей силой, руководящей происходящим, ожидаемо оказывается Бог, но видение истории теперь совсем не похоже на провиденциализм глав, посвященных падению Константинополя. Бог теперь творит историю единого неразделенного народа империи, а не греков под властью иноверцев. Он возносит одних и приводит к гибели других претендентов на османский трон вне какой-либо связи с грехами или, напротив, благочестием греков, и греки-христиане на несколько страниц полностью пропадают из поля зрения рассказчика. Чтобы проиллюстрировать эмоциональный настрой глав, достаточно нескольких примеров: «Но Бог не присудил ему (старшему сыну Баязида Шехзаде Ахмету. - Л. Л.) получить царство» ${ }^{50}$, «Но взгляни на деяния Божии. Ибо кто уразумел дух Господа, и был

\footnotetext{
${ }^{48}$ Ecthesis. P. 92. Cap. 73.

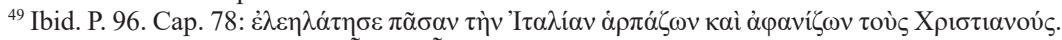

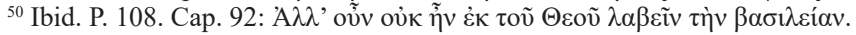




\section{Л. В. Луховицкий}

советником у Него (Ис. 40:13)?» ${ }^{51}$, «Ибо Бог не дал ему воцариться. Ведь всякий совершенный дар - свыше» ${ }^{52}$. Подданные султана больше не разделены на христиан и мусульман, а мыслятся как некое единство: «Так любил его (Баязида. - Л. Л.) весь народ, что и девочки, и мальчики, и младенцы лепетали его имя» ${ }^{53}$.

Мировоззрение автора «Хронологического изложения» внутренне противоречиво. Предложенный в настоящей статье подход - это только один из множества возможных способов найти ключ к пониманию природы этих противоречий. Хроникальная форма произведения искажает перспективу, создавая иллюзию жанровой определенности. В действительности, разные части сочинения фактически написаны в разных жанрах, сформировавшихся еще в византийскую эпоху, и перенимают не только формальные приемы и образность, но и систему ценностей, свойственную этим жанрам. На первый взгляд, чередование кажется механистическим, а переходы от одной части к другой - произвольными и безыскусными. Однако по мере погружения в текст у читателя возникает ощущение авторской неудовлетворенности имеющимися в его распоряжении моделями. Реальная жизнь не умещается в жесткие рамки ламентаций и панегириков, и рассказчик начинает испытывать сочувствие к героям истории вне зависимости от их религии и языка. Автор «Хронологического изложения» предстает не расчетливым компилятором, а чутким писателем, который пытается нащупать новый тип повествования, подходящий для описания социальной реальности, принципиально не похожей на ту, что отражали авторы эпохи падения Константинополя.

\section{REFERENCES}

Bekker, I. (Ed.). (1849). Historia politica et patriarchica Constantinopoleos. Epirotica. Bonn: Impensis Ed. Weberi.

Cuomo, A. M. (Ed.). (2016). Ioannis Canani de Constantinopolitana obsidione relatio: a Critical Edition, with English Translation, Introduction, and Notes of John Kananos' Account of the Siege of Constantinople in 1422. Boston; Berlin: De Gruyter.

Jouanno, C. (2016). Shared Spaces: 1. Digenis Akritis, the Two-Blood Border Lord. In C. Cupane, \& B. Krönung (Eds.), Fictional Storytelling in the Medieval Eastern Mediterranean and Beyond (pp. 260-284). Leiden: Brill.

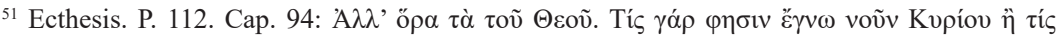
бú $\mu \beta$

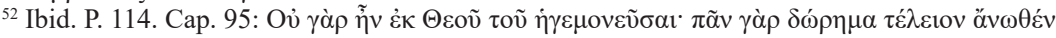
$\dot{\varepsilon} \sigma \tau \mathrm{\tau}$.

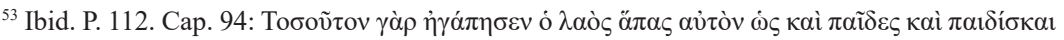

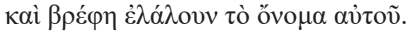


Художественный мир поствизантийской хронистики

Lambros, S. P. (Ed.). (1902). Ecthesis Chronica and Chronicon Athenarum. London: Methuen Publishing.

Lukhovitskiy, L. (2016), “Umer nechestivyi emir... on ochen' liubil i samikh khristian, i tserkov' Khristovu": Grecheskoe samosoznanie v khronistike nachala XVII v. In M. Bibikov, \& K. Klimova (Eds.), Kafedra vizantiiskoi i novogrecheskoi filologii (pp. 30-43). Moscow: Izdatel'stvo MGU.

Mai, A. (Ed.). (1842). Germani Constantinopolitani De haeresibus et synodis. In A. Mai (Ed.), Spicilegium Romanum (Vol. 7, pp. 1-74). Rome: Typis Collegii Urbani.

Moustakas, K. (2011). Byzantine "Visions" of the Ottoman Empire: Theories of Ottoman Legitimacy by Byzantine Scholars after the Fall of Constantinople. In A. Lymberopoulou (Ed.), Images of the Byzantine World: Visions, Messages and Meanings: Studies Presented to L. Brubaker (pp. 215-229). Farnham; Burlington: Ashgate.

Moustakas, K. (2014). The Logic of Historical Thematology in the Historia Politica Constantinopoleos and the Historia Patriarchica Constantinopoleos. In E. Balta, G. Salakidis, \& Th. Stavrides (Eds.), Festschrift in Honor of I. P. Theocharides: Studies on the Ottoman Empire and Turkey (Vol. 2, pp. 363-374). Istanbul: The Isis Press.

Moustakas, K. (2019). Ottoman Greek Views of Ottoman Rule $\left(15^{\text {th }}-16^{\text {th }}\right.$ Centuries): The Perspective of the Patriarchate Associates. In M. Sariyannis (Ed.), Political Thought and Practice in the Ottoman Empire: Halcyon Days in Crete 9: A Symposium Held in Rethymno 9-11 January 2015 (pp. 311-318). Rethymno: Crete University Press.

Philippides, M. (2008). Damaskenos the Studite. In C. Kafadar, H. Karateke, \& C. Fleischer (Eds.), Historians of the Ottoman Empire. Retrieved from https:// ottomanhistorians.uchicago.edu/en/historians/26

Philippides, M. (Ed.). (1990). Emperors, Patriarchs, and Sultans of Constantinople, 1373-1513: An Anonymous Greek Chronicle of the Sixteenth Century. Brookline (Mass.): Hellenic College Press.

Philippides, M., \& Hanak, W. K. (2011). The Siege and Fall of Constantinople in 1453: Historiography, Topography, and Military Studies. Farnham; Burlington: Ashgate.

Polyviannyi, D. (2019). "Bolgarskaia anonimnaia khronika": opyt analiticheskoi dekompozitsii ["Bulgarian Anonymus Chronicle": Essay on Analytical Decomposition]. Vestnik Volgogradskogo gosudarstvennogo univesiteta. Seriia 4. Istoriia, Regionovedenie, Mezhdunarodnye otnosheniia, 24, 6, 173-183. doi: 10.15688/ jvolsu4.2019.6.14

Reinsch, D. R. (1985). Byzantinisches Herrscherlob für den türkischen Sultan: Ein bisher unbekanntes Gedicht des Georgios Amirutzes auf Mehmed den Eroberer. In L. Burgmann, M. Th. Fögen, \& A. Schminck (Eds.), Cupido legum (pp. 195-210). Frankfurt am Main: Löwenklau Gesellschaft.

Reinsch, D. R. (2009). Mehmet der Eroberer in der Darstellung der zeitgenössischen byzantinischen Geschichtsschreiber. In N. Asutay-Effenberger, \& U. Rehm (Eds.), Sultan Mehmet II. Eroberer Konstantinopels, Patron der Künste (pp. 15-30). Cologne: Böhlau Verlag. 


\section{Л. В. Луховицкий}

Sakel, D. (2006). A Probable Solution of the Problem of the Chronicle of the Turkish Sultan. In J. Burke et al. (Eds.), Byzantine Narrative: Papers in Honour of R. Scott (pp. 204-220). Leiden; Boston: Brill. doi: 10.1163/9789004344877_016

Sakel, D. (2010). A Non-Existent Byzantine-Style Historian in a New Encyclopaedia of Ottoman Historians. Revue des études byzantines, 68, 209-217. doi: 10.3406/rebyz.2010.3071

Sakel, D. (2013a). An Addendum on Codex Constantinopolitanus Metochion Sanctae Sepulchri 462. Hellenika, 63, 171-173.

Sakel, D. (2013b). The Chronicle of 1570: The Original Version. Byzantinische Zeitschrift, 106(1), 143-152. doi: 10.1515/bz-2013-0011

Sakel, D. (2013c). The Manuscripts of the Chronicle of 1570. Byzantion, 83, 363-374. doi: 10.2143/BYZ.83.0.2988923

Shawcross, T. (2009). The Chronicle of Morea: Historiography in Crusader States. Oxford: Oxford University Press.

Todorova, M. (1997). Imagining the Balkans. Oxford: Oxford University Press.

Vincent, A. (1998). Byzantium Regained? The History, Advice and Lament by Matthew of Myra. Thesaurismata, 28, 275-347.

Луховицкий Лев Всеволодович кандидат филологических наук, научный сотрудник

Институт славяноведения РАН 119991, Москва, Ленинский пр., 32А E-mail: lukhovitskiy@gmail.com

\section{Lukhovitskiy, Lev Vsevolodovich}

$\mathrm{PhD}$ (Philology), Researcher

Institute of Slavic Studies of the Russian

Academy of Sciences

32A Leninskii Ave, Moscow, 119991,

Russia

E-mail: lukhovitskiy@gmail.com

ORCID: 0000-0001-9681-2350

ResearcherID: G-8321-2015

ScopusID: 56780482700 